\title{
Estimate the Pollution Tolerance Level of Farmers in the Noyyal River Bain of Tamil Nadu, India
}

\author{
A. Anitha Pauline ${ }^{1 *}$ and C. Karthikeyan ${ }^{2}$ \\ ${ }^{1}$ Women Scientist Fellow (DST), TNAU., India \\ ${ }^{2}$ Department of Agricultural Extension \& Rural Sociology, \\ Tamil Nadu Agricultural University, Coimbatore-641003, India \\ *Corresponding author
}

\section{A B S T R A C T}

The study aims to assess the pollution tolerance level of the farmers in the Noyyal river basin of Tamil Nadu. Pollution tolerance level is a cognitive behaviour, denotes the extent to which the farmers express their adjustability with regard to different pollution causing factors. The study was conducted in Tiruppur and Erode districts of Tamil Nadu. From

\section{Keywords}

Pollution tolerance level, Noyyal river basin, Dyeing pollution

\section{Article Info}

Accepted:

20 June 2018

Available Online:

10 July 2018 each district one block was selected. Six revenue villages at the rate of three from each block were selected. The respondents were categorized into affected and unaffected farmers based on their proximity to Noyyal river as well as well water quality parameters. A sample of 90 farmers from each category (affected and not affected) was considered for the study. Totally 180 farmers were selected. The responses were obtained on a three point continuum and chi-square value was worked out to determine the significance of difference between the perception by the respondents of both the areas with respect to each of the statement. In both areas, cent per cent of the respondents perceived positively 'agreed' the following statements such as 'industries leading to water pollution should not be permitted in the village locality' (S-4), 'industries that have the technology for treating waste water alone should be encouraged' (S-5), 'industries depleting ground water should be discouraged' (S-8), 'conversion of agricultural lands for industrial purpose should be avoided' (S-9), 'industries causing air pollution should be avoided in the village locality' (S-14) 'industries disposing more of solid wastes should not be established in the village locality’ (S-15).

\section{Introduction}

The study aims to assess the pollution tolerance level of the farmers in the Noyyal river basin of Tamil Nadu. Pollution tolerance level is a cognitive behaviour, denotes the extent to which the farmers express their adjustability with regard to different pollution causing factors. Pollution problems are increasing with the increase in the population along with acceleration of industrialization. Several ecological studies made in respect of pollution due to industrial and other human activities revealed undesirable habitat transformations, which gradually rendered the area unsuitable for plant growth, animal 
habitation and even human settlement. In the years to come, the impact of above ecological issues on our economic activities especially farming, is bound to be far reaching and therefore cannot be lost sight of in our planning process. Keeping in view, in order to determine the level of tolerance of environmental condition, with a view towards conservation and preservation of environmental quality of the locality, an attempt was made to analyse the kind of environment which the farming community prefers in the context of attaining a suitable development. This is termed as the Pollution Tolerance Level of the farming community. The measure developed by Alauddin (1996) was used with slight modifications according to this study.

\section{Materials and Methods}

In the present study, it was contemplated to explore impact of dyeing industrial pollution on migration. Therefore, in consultation with the experts involved in the environmental protection, Public Works Department (PWD), Tamil Nadu Pollution Control Board (TNPCB), scientists involved in the environmental research, officials of the development departments viz., agriculture, animal Husbandry, fisheries and the experts in the field of agricultural extension and agricultural economics, it was decided to select the study area where agriculture is the main occupation with more proneness towards dyeing industrial pollution. In Tamil Nadu four major districts Viz., Coimbatore, Erode, Tiruppur and Karur had major dyeing industries. Out of these districts Tiruppur and Erode districts were selected purposively, because these two districts had more number of dyeing industries which affect the water resources, land, human and livestock. (Industrial Profile of Karur District: 2012-13). Tiruppur block from Tiruppur district and Chennimalay block from Erode district were purposively selected for the study based on the following criteria. Tiruppur block is in the upstream of Noyyal River and consisted of many dyeing and bleaching industries. Similarly Chennimalay block is in the downstream of Noyyal River where effluents were stored in the Orathupalayam dam. These two blocks were severely affected due to dyeing industrial effluents. (Source: Department of Environmental Science, 2012). From the selected blocks, six revenue villages were selected and accordingly, three revenue villages from Tiruppur and Erode districts were selected. A sample size of 90 farmers from each category (affected and unaffected) was considered for the study. Totally 180 farmers were selected. Farmers were randomly selected for interview from two areas (affected and unaffected) with similar social and ecological conditions except pollution intervention. The selection of affected and unaffected area was based on their distance from industrial zones and their well water quality standards.

The number of respondents from each of the selected village was fixed based on the Proportionate Random Sampling (PRS) method. Data were collected through pretested interview schedule. The data were analyzed by using appropriate statistical tools and the significant findings are given here under. To estimate the pollution tolerance level of the farmers, the measure developed by Alauddin (1996) was used with slight modifications according to this study. Finally fifteen items/ statements were included for the study.

\section{Selection of statements under pollution tolerance level}

The selection of statements was done based on the consensus approach and item analysis approach. 


\section{Consensus approach}

Consensus approach means a panel of judges evaluate the items chosen for inclusion in the instrument in order to find out whether they are relevant to the specified domain and possess adequate clarity and representation. Accordingly, a list of identified major components and its sub components were distributed to 50 scientists of various institutions like Tamil Nadu Agricultural University, Coimbatore, Kerala Agricultural University, Thrissur, Annamalai University, Chidambaram, Gandhigram Rural University, Dindugul, Sugarcane Breeding Institute, Coimbatore and Central Institute of Cotton Research, Coimbatore. Responses were obtained from 35 judges. The judges were earlier asked to judge the components on a three point continuum as a 'relevant', 'somewhat relevant' and 'not relevant'. The weightages assigned were $3,2,1$ for 'relevant', 'somewhat relevant' and 'not relevant' respectively.

\section{Item analysis approach}

The judges' scores arrived were subjected to item analysis approach for the selection of statements.

The Relevancy Co-efficient Index (RCI) for each statement was worked out by using the following formula devised by Ramanna (1999).

$\mathrm{RCI}=$

Total score of all the judges on the $i^{\text {th }}$ item $x$ Total number of judges

Maximum score in the continuum

Considering relevancy weightage, the components were screened for their relevancy. Accordingly, components having relevancy weightage of more than 0.75 were considered.
Using this process, final set of statements were selected for final administration.

The items/ statements were administered to the affected respondents and requested to rate each item/ statement against three point continuum namely 'tolerate', 'partially tolerate' and 'not at all tolerate' and the weightage of three, two and one were assigned to the responses, respectively. The total score was obtained for each item/ statement and was taken into account for the purpose of calculations.

This is termed as the Pollution Tolerance Level of the farming community. The measure developed by Alauddin (1996) was used with slight modifications according to this study. Finally, fifteen items/ statements were included for the study. The items/ statements were administered to both (affected and unaffected) respondents and requested to rate each item/ statement against three point continuum namely 'tolerate', 'partially tolerate' and 'not at all tolerate' and the weightage of three, two and one were assigned to the responses, respectively. The responses were obtained on a three point continuum and chi-square value was worked out to determine the significance of difference between the perception by the respondents of both the areas with respect to each of the statement and the results are depicted in Table 2. The list of statements along with code numbers are furnished in Table 1 .

\section{Results and Discussion}

The results on the pollution tolerance level of the farmers from both affected and notaffected areas are discussed below. The list of statements along with code numbers are furnished in Table 1.

An over view of the data furnished in Table 2 indicates that out of fifteen statements, 
statistically significant difference in responses were exhibited at 0.01 level of probability with regard to the statements viz., S-1, S-3, S6, S-7, S-9, S-10, S-11, S-13 and S-14. Among the fifteen statements, four statements were significant at 0.05 level of probability such as $\mathrm{S}-2, \mathrm{~S}-5, \mathrm{~S}-8$ and $\mathrm{S}-12$. All the remaining statements were found to be non-significant.

In the affected areas, cent per cent of the respondents perceived positively as 'agree' to 'somewhat agree' for the following the statements such as (S-4), (S-5), (S-8), (S-9), (S-14) and (S-15).

The statements are as follows: 'industries leading to water pollution should not be permitted in the village locality' (S-4), 'industries that have the technology for treating waste water alone should be encouraged' (S-5), 'industries depleting ground water should be discouraged' (S-8), 'conversion of agricultural lands for industrial purpose should be avoided' (S-9), 'industries causing air pollution should be avoided in the village locality' (S-14) 'industries disposing more of solid wastes should not be established in the village locality' (S-15). In the same area statements such as (S-1) (S-2), (S-3), (S-6) and (S-13) were agreed by a majority of the respondents viz., 'avoiding more number of industries in village surroundings' (80.00\%), 'better to have industries in village surroundings which do not impact agriculture' (97.78\%), 'agro based industries should be encouraged at village surroundings' $(75.56 \%)$, 'avoiding industries which could provide employment to majority of village people' $(80.00 \%)$ and 'restriction in settlement of migrates in the village locality' $(64.44 \%)$ were perceived as 'agree' by majority of the respondents.

From the above findings it is concluded that in the affected area, statements such as (S-1) (S2), (S-3) (S-4), (S-5), (S-6), (S-8), (S-9), (S-
13), (S-14) and (S-15) were perceived as 'agree' to 'somewhat agree' by a majority of the respondents.

In the similar way, respondents from unaffected area, more than three-fourth of the respondents perceived as 'agree' to 'somewhat agree' for the following statements such as (S2) (S-4), (S-5), (S-8), (S-9), (S-14) and (S-15). The statements are as follows: 'better to have industries in village surroundings which do not impact agriculture' (91.11\%), 'industries leading to water pollution should not be permitted in the village locality' (97.78\%), 'industries that have the technology for treating waste water alone should be encouraged' (94.45\%), 'industries depleting ground water should be discouraged' $(95.60 \%)$, 'conversion of agricultural lands for industrial purpose should be avoided' (87.77\%), 'avoiding industries causing air pollution' (84.40) and 'avoiding industries disposing more of solid wastes' (97.78\%). In the same area, more than two-thirds of the respondents 'agreed' upon the following statements such as (S-1), (S-6) and (S-10) viz., 'avoiding more number of industries in village surroundings' (72.22\%), 'avoiding industries which could provide employment to majority of village people' $(66.67 \%)$ and 'infrastructure facilities got increased due to industrialisation which improved the standards of living of the rural community' (S-10).

From the above findings, it is concluded that in the unaffected area, statements such as (S1), (S-2), (S-4), (S-5), (S-6), (S-8), (S-9), (S$10)$, (S-14) and (S-15) were perceived as agreed by majority of the respondents.

In both the areas, out of fifteen statements ten statements were commonly 'agreed' by the respondents in the study area. The statements include (S-1) (S-2), (S-4), (S-5), (S-6), (S-8), (S-9), (S-13), (S-14) and (S-15). This might be attributed to the fact that the respondents of 
polluted area were facing the problems such as shortage of adequate labour for agricultural work, hike in the cost of labour, loss of morale and work efficiency and reduction in the quality and quantity of ground water for irrigation and drinking purpose, in a more severe way than the respondents of nonpolluted area.

As a result, the respondents from affected area might have perceived such aspects more strongly than the respondents of unaffected area. From the above findings, it is concluded that industrialization not only affect the surroundings areas, but also affected the environment and social structure of the people in the nearby areas. Industrialization has negative effects on environment and society. Environmentally, industrialization both pollutes the environment and depletes its resources. Socially, industrialization changes a society in many ways. People move to cities and break family ties.

Table.1 Statements and code numbers of pollution tolerance level

\begin{tabular}{|c|c|c|}
\hline S.No. & Code number & Statements \\
\hline 1. & S-1 & $\begin{array}{l}\text { It is better to avoid more number of industries in village } \\
\text { surroundings }\end{array}$ \\
\hline 2. & S-2 & $\begin{array}{l}\text { It is better to have in village surroundings industries which do not } \\
\text { impact agriculture }\end{array}$ \\
\hline 3. & S-3 & Agro based industries should be encouraged at village surroundings \\
\hline 4. & S-4 & $\begin{array}{l}\text { Industries leading to water pollution should not be permitted in the } \\
\text { village locality }\end{array}$ \\
\hline 5. & S-5 & $\begin{array}{l}\text { Industries that have the technology for treating waste water alone } \\
\text { should be encouraged }\end{array}$ \\
\hline 6. & S-6 & $\begin{array}{l}\text { It is better to avoid industries which could provide employment to } \\
\text { majority of village people }\end{array}$ \\
\hline 7. & S-7 & $\begin{array}{l}\text { Industries which do not rely more on labour force, should be } \\
\text { established at far off places }\end{array}$ \\
\hline 8. & S-8 & Industries depleting ground water should be discouraged \\
\hline 9. & S-9 & $\begin{array}{l}\text { Conversion of agricultural lands for industrial purpose should be } \\
\text { avoided }\end{array}$ \\
\hline 10. & S-10 & $\begin{array}{l}\text { Infrastructure facilities got increased due to industrialisation which } \\
\text { improved the standards of living of the rural community }\end{array}$ \\
\hline 11. & S-11 & $\begin{array}{l}\text { It is better to have industries which do not destruct the naturalness } \\
\text { of the village atmosphere }\end{array}$ \\
\hline 12. & S-12 & $\begin{array}{l}\text { It is better to avoid industries that caused social imbalance and } \\
\text { cultural disharmony }\end{array}$ \\
\hline 13. & S-13 & $\begin{array}{l}\text { Excessive settlement of migrators in the village locality, results in } \\
\text { the hike of land cost and other local commodities and therefore, it } \\
\text { should be restricted to a limit. }\end{array}$ \\
\hline 14. & S-14 & $\begin{array}{l}\text { The industries causing air pollution should be avoided in the village } \\
\text { locality }\end{array}$ \\
\hline 15. & S-15 & $\begin{array}{l}\text { The industries disposing more of solid wastes should not be } \\
\text { established in the village locality }\end{array}$ \\
\hline
\end{tabular}


Table.2 Distribution of respondents based on their perceived Pollution Tolerance Level (PTL)

\begin{tabular}{|c|c|c|c|c|c|c|c|c|}
\hline \multirow{2}{*}{$\begin{array}{l}\text { Statement } \\
\text { (code } \\
\text { numbers) }\end{array}$} & \multirow[t]{2}{*}{ Zones (Z) } & \multicolumn{2}{|c|}{ Agree } & \multicolumn{2}{|c|}{$\begin{array}{l}\text { Somewhat } \\
\text { agree }\end{array}$} & \multicolumn{2}{|c|}{ Disagree } & \multirow[t]{2}{*}{$\begin{array}{l}\text { Chi- } \\
\text { square }\end{array}$} \\
\hline & & No. & $\%$ & No. & $\%$ & No. & $\%$ & \\
\hline \multirow[t]{2}{*}{ S-1 } & Affected & 72 & 80.00 & 18 & 20 & - & - & \multirow[t]{2}{*}{$7.283^{* *}$} \\
\hline & Un affected & 65 & 72.22 & 20 & 22.22 & 5 & 5.55 & \\
\hline \multirow[t]{2}{*}{ S-2 } & Affected & 88 & 97.78 & 2 & 2.22 & - & - & \multirow[t]{2}{*}{$3.812^{*}$} \\
\hline & Un affected & 82 & 91.11 & 8 & 8.89 & - & - & \\
\hline \multirow[t]{2}{*}{ S-3 } & Affected & 68 & 75.56 & 18 & 20.00 & 4 & 4.44 & \multirow[t]{2}{*}{$58.08^{* *}$} \\
\hline & Un affected & 17 & 18.88 & 57 & 63.33 & 16 & 17.77 & \\
\hline \multirow[t]{2}{*}{ S-4 } & Affected & 90 & 100.00 & - & - & - & - & \multirow[t]{2}{*}{$0.339^{\mathrm{NS}}$} \\
\hline & Un affected & 88 & 97.78 & 2 & 2.22 & - & - & \\
\hline \multirow[t]{2}{*}{ S-5 } & Affected & 90 & 100.00 & - & - & - & - & \multirow[t]{2}{*}{$5.143^{*}$} \\
\hline & Un affected & 85 & 94.45 & 5 & 5.55 & - & - & \\
\hline \multirow[t]{2}{*}{ S-6 } & Affected & 72 & 80.00 & 18 & 20.00 & - & - & \multirow[t]{2}{*}{$26.000^{* *}$} \\
\hline & Un affected & 60 & 66.67 & 20 & 22.22 & 10 & 11.11 & \\
\hline \multirow[t]{2}{*}{ S-7 } & Affected & 13 & 14.44 & 77 & 85.56 & - & - & \multirow[t]{2}{*}{$11.790^{* *}$} \\
\hline & Un affected & 4 & 4.44 & 79 & 87.78 & 7 & 7.78 & \\
\hline \multirow[t]{2}{*}{ S-8 } & Affected & 90 & 100.00 & - & - & - & - & \multirow[t]{2}{*}{$4.091^{*}$} \\
\hline & Un affected & 86 & 95.60 & 4 & 4.40 & - & - & \\
\hline \multirow[t]{2}{*}{ S-9 } & Affected & 90 & 100.00 & - & - & - & - & \multirow[t]{2}{*}{$11.716^{* *}$} \\
\hline & Un affected & 79 & 87.77 & 11 & 12.22 & - & - & \\
\hline \multirow[t]{2}{*}{ S-10 } & Affected & 6 & 6.67 & 83 & 92.22 & 1 & 1.11 & \multirow[t]{2}{*}{$82.747^{* *}$} \\
\hline & Un affected & 62 & 68.90 & 23 & 25.55 & 5 & 5.55 & \\
\hline \multirow[t]{2}{*}{ S-11 } & Affected & 14 & 15.55 & 76 & 84.45 & - & - & \multirow[t]{2}{*}{$43.448^{* *}$} \\
\hline & Un affected & 18 & 20.00 & 55 & 61.11 & 17 & 18.89 & \\
\hline \multirow[t]{2}{*}{ S-12 } & Affected & 16 & 17.77 & 74 & 82.22 & - & - & $10.548^{*}$ \\
\hline & Un affected & 7 & 7.77 & 76 & 84.46 & 7 & 7.77 & \\
\hline S-13 & Affected & 58 & 64.44 & 17 & 18.90 & 15 & 16.66 & $98.088^{* * *}$ \\
\hline & Un affected & 20 & 22.22 & 56 & 62.22 & 14 & 15.56 & \\
\hline S-14 & Affected & 90 & 100.00 & - & - & - & - & $15.181^{* *}$ \\
\hline & Un affected & 76 & 84.44 & 14 & 15.56 & - & - & \\
\hline S-15 & Affected & 90 & 100.00 & - & - & - & - & $3.051^{\mathrm{NS}}$ \\
\hline & Un affected & 87 & 96.70 & 3 & 3.30 & & & \\
\hline
\end{tabular}

(** Significant at $0.01 \%, *$ significant at $0.05 \%$ and NS- Non-significant) 
Table.3 Pollution Tolerance Level (PTL) - perceived value of aspects

\begin{tabular}{|c|c|c|c|c|c|c|c|}
\hline S.No. & $\begin{array}{c}\text { Statement } \\
\text { code } \\
\text { numbers }\end{array}$ & \multicolumn{2}{|c|}{ Total Score } & \multicolumn{2}{|c|}{ Mean Score } & \multicolumn{2}{|c|}{ Rank } \\
\hline 1. & Affected & Unaffected & Affected & Unaffected & Affected & Unaffected \\
\hline 2. & 252 & 240 & 2.80 & 2.66 & III & VII \\
\hline 3. & S-2 & 268 & 262 & 2.97 & 2.91 & II & IV \\
\hline 4. & S-3 & 244 & 181 & 2.71 & 2.01 & IV & XI \\
\hline 5. & S-4 & 270 & 268 & 3.00 & 2.97 & I & I \\
\hline 6. & S-5 & 252 & 265 & 3.00 & 2.94 & 111 & III \\
\hline 7. & S-7 & 270 & 230 & 3.00 & 2.55 & I & IX \\
\hline 8. & S-8 & 270 & 177 & 2.14 & 1.96 & VIII & XIII \\
\hline 9. & S-9 & 270 & 259 & 3.00 & 2.95 & I & II \\
\hline 10. & S-10 & 185 & 237 & 2.05 & 2.63 & IX & VIII \\
\hline 11. & S-11 & 194 & 181 & 2.15 & 2.01 & VII & XI \\
\hline 12. & S-12 & 196 & 180 & 2.17 & 2.00 & VI & XII \\
\hline 13. & S-13 & 223 & 186 & 2.47 & 2.06 & V & X \\
\hline 14. & S-14 & 270 & 256 & 3.00 & 2.84 & I & VI \\
\hline 15. & S-15 & 270 & 268 & 3.00 & 2.97 & I & I \\
\hline
\end{tabular}

Further, it could be observed from Table 2 that in the affected area, more than three-fourth of the respondents perceived 'somewhat agreed' to the following statements with respect to pollution tolerance level such as (S-7), (S-10), (S-11) and

$(\mathrm{S}-12)$.

The statements are 'industries which do not rely more on labour force should be established at far off places' (85.56\%), 'infrastructure facilities got increased due to industrialisation which improved the standards of living of the rural community' (92.22\%), 'better to have industries which do not destruct the naturalness of the village atmosphere' ( $84.45 \%)$ and 'better to avoid industries caused social imbalance and cultural disharmony' (82.22\%) were expressed by majority of the respondents in the affected area. In the unaffected area, a majority of the respondents were found to be 'somewhat agreed' to the following the statements such as (S-3), (S-7), (S-11), (S-12) and (S-13). The statements include; 'only agro based industries should be encouraged at village surroundings' (63.33\%) 'industries which do not rely more on labour force, should be established at far off places' $(87.78 \%)$, 'better to have industries which do not destruct the naturalness of the village atmosphere' (61.11\%), 'better to avoid industries that caused social imbalance and cultural disharmony' (84.46\%) and 'restriction in settlement of migrates in the village locality' $(62.22 \%)$ were perceived as somewhat agree by a majority of the respondents. 
From the findings, it is interpreted that statements such as (S-7), (S-11), (S-12) were found to be 'somewhat agree' in both the areas. The reason might be that the respondents of the both the areas were not in favour of having few industries like industries causing water pollution, air pollution, societal pollution and industries rely on much labour force in their locality. In both areas, the respondents reported that agro based industries should be encouraged in the village locality, and industries with technology for treating waste water alone should be encouraged were reported by a majority of the respondents. Most of the respondents felt that infrastructure facilities got increased due to industrialisation, which improved the standards of living of the rural community.

From the above findings, it is clearly seen that in both areas, people are not against for industrialization. They want industries which do not disturb their livelihoods.

The increased prosperity and standard of living of people is evident in various forms such as better and more food, clothing and shelter, longer life expectancy, freedom from drudgery of physical work, more and better means of entertainment and other leisure activities, better facilities for development of intellectual capabilities of individuals for satisfying their intellectual inquisitiveness, and greater interaction among people through better means of communication and travel.

\section{Pollution Tolerance Level (PTL) - perceived value of aspects}

For this purpose, total and mean scores were calculated for each statements/items of both affected and unaffected farmers and Spearman's rank correlation was used to rank the statements/items. The results of the analysis are presented in Table 3 and list of the statements are presented in Table 1.

From the results projected in Table 3 , it could be inferred that there is statistically significant agreement between the rankings given by the respondents of both the areas. This meant that the two categories of respondents significantly agreed with each other in their perceived PTL. This exclusively showed that the respondents of both polluted and non-polluted areas did not differ in their perception regarding the relative potency of the 15 aspects pertaining to PTL.

It could be inferred further that there appeared to be more consensus among two groups of respondents, as they have attached high value to the following aspects expressed in the form of statements such as industries leading to water pollution should not be permitted in the village locality' (S-4), 'industries that have the technology for treating waste water alone should be encouraged' (S-5), 'industries depleting ground water should be discouraged' (S-8), 'conversion of agricultural lands for industrial purpose should be avoided' (S-9), 'industries causing air pollution should be avoided in the village locality' (S-14) and 'industries disposing more of solid wastes should not be established in the village locality' (S-15) by assessing first five ranks. The farmers of both the areas were having strong opinion that they dislike by establishing a variety of industries, not compatible with the agriculture of the locality, as they cause irreparable harm to their livelihood occupation and to the general well being of the farming community which in turn lead to some serious repercussions in their socio-economic condition. This might be the cause for the result.

The aspects which were given second order of importance by assigning the next five ranks i.e. $6^{\text {th }}$ to $10^{\text {th }}$, by the respondents of both the areas were: 'avoid more number of industries in the village locality' (S-1), 'only agro based industries should be encouraged at village surroundings' (S-3), 'better to avoid industries which could provide employment to majority of village people' (S-6), 'industries which do not rely more on labour force, should be established at far off places' (S-7) and 'infrastructure facilities got increased due to industrialisation which improved the standards of living of the rural community'(S-10). This clearly showed 
that farming community preferred the agro based industries and they want industries which do not affect the natural and social ecosystem.

It is concluded, from this study, it is clearly noted that the farming community was drastically affected by the dyeing industrial effluents in Tiruppur and Erode districts. There existed significant differences among the affected and unaffected respondents with respect to pollution tolerance levels. The affected farmers in the study area shifted their farm occupation to non - farm occupation. An action model was suggested based on the implications drawn out of the results to the Researchers, Extension workers, Tamil Nadu Pollution Control Board and Government of Tamil Nadu to take actions based on the recommendations, so that the affected farmers could be benefitted.

1. Majority of the farmers had high level of pollution tolerance level. It indicates that farmers needed only agro-based industries in the village locality. So industries that disposed water and solid wastes should not be permitted in the village locality.

2. Farmers from affected area expected more research on soil and water reclamation process to overcome dyeing industrial effluents in the Noyyal river basin. So scientists from the Environmental Science should work towards soil and water reclamation process.

3. The agricultural land value decreased and agricultural loss increased due to the impact of pollution. The farmers spent on pollution averting measures as an additional cost of production. Taxing mechanism should be framed to collect the money from dyeing factories letting out untreated effluents and compensate the farming community.

4. Soil testing and soil reclamation may be strengthened and taken up on large scale basis at subsidised cost by the Department of Agriculture.

5. Location specific cropping pattern emerging from the field may be further studied and popularised for adoption. Incentives may be given for cultivation of crops with lesser demands on water and energy inputs.

6. On the basis of the extent and magnitude of damage to the villages, especially the farmers, may be given compensation for their loss on the basis of "polluters pay" concept. 'Polluters pay principle' should be used to account the polluters' inaction in reducing / preventing pollution.

7. A community health insurance programme may be introduced to enhance the social security of the people of the area against the health hazards of pollution.

\section{References}

Alauddin, A. S. (1996). Environmental Pollution: An Impact Assessment on the Farming Sector. Unpub. Ph.D. Thesis, Tamil Nadu Agricultural University, Coimbatore.

Ramanna, K.N. (1999). People's Participation in Planning and Implementation of Integrated Watershed Development Programme- A Comparative Study of Watersheds of Government vis-à-vis NGO. Unpub. Ph.D Thesis, TNAU, Coimbatore.

\section{How to cite this article:}

Anitha Pauline, A. and Karthikeyan, C. 2018. Estimate the Pollution Tolerance Level of Farmers in the Noyyal River Bain of Tamil Nadu, India. Int.J.Curr.Microbiol.App.Sci. 7(07): 2954-2962. doi: https://doi.org/10.20546/ijcmas.2018.707.345 